\title{
The Sexual Diversity Debate in Brazilian Psychology: Professional Regulation at Stake
}

\author{
Cleber Michel Ribeiro de Macedo ${ }^{1}$ \\ ${ }^{1}$ Universidade do Estado do Rio de Janeiro, RJ, Brasil.
}

\author{
Horacio Federico Sívori ${ }^{1}$ \\ ${ }^{1}$ Universidade do Estado do Rio de Janeiro, RJ, Brasil.
}

\begin{abstract}
So-called "sexual reorientation therapies" represent a challenge to the scientific and professional development of Psychology, and to the exercise and free expression of sexual orientation as a human right. Since 1999 the Brazilian Federal Council of Psychology (CFP) has implemented a ban against the pathologization of homosexuality. The validity of that normative instrument, known as Resolution 01/99, has been contested by moral entrepreneurs within the profession, self-identified as Evangelical Christians, who pose a broader challenge to Psychology, standing as a secular, science-based profession. The controversy created by the challenge to CFP's positions on homosexuality and on religion extrapolates the domain of Psychology and its regulation as a science and profession, and becomes one more dispute related to sexual politics in Brazil. In this paper we explore the process by which sexual diversity has become a contentious issue for Brazilian Psychology, affecting the politics and regulation of the profession.
\end{abstract}

Keywords: Psychology, Sexual Diversity, Homosexuality, Religion, Pentecostalism.

\section{O Debate sobre Diversidade Sexual na Psicologia Brasileira: Regulamentação Profissional em Jogo}

Resumo: As chamadas "terapias de reorientação sexual" representam um desafio para o desenvolvimento científico e profissional da Psicologia, bem como para o exercício e livre expressão da orientação sexual como um direito humano. Desde 1999, o Conselho Federal de Psicologia (CFP) brasileiro implementou uma proibição contra a patologização da homossexualidade. A validade desse instrumento normativo, conhecido como Resolução $\mathrm{n}^{\circ}$ 01/1999, tem sido contestada por empreendedores morais dentro da profissão, autoidentificados como cristãos evangélicos. Sua atuação coloca um desafio mais amplo à posição da Psicologia como uma profissão secular de base científica. A controvérsia criada pelo desafio às posições do CFP sobre homossexualidade e sobre religião extrapola o domínio da Psicologia e da sua regulamentação como ciência e profissão, para se tornar mais uma disputa sobre a política sexual no Brasil. Neste artigo, exploramos o processo pelo qual a diversidade sexual tornou-se uma questão contenciosa para a Psicologia brasileira, que afeta a política e a regulamentação da profissão.

Palavras-chave: Psicologia, Diversidade Sexual, Homossexualidade, Religião, Pentecostalismo. 


\title{
El Debate sobre la Diversidad Sexual en la Psicología Brasileña: la Regulación Profesional en Juego
}

\begin{abstract}
Resumen: Las llamadas "terapias de reorientación sexual” representan un desafío para el desarrollo científico y profesional de la Psicología, así como para el ejercicio y libre expresión de la orientación sexual como un derecho humano. Desde 1999, el Consejo Federal de Psicología (CFP) brasileño implementó una prohibición contra la patologización de la homosexualidad. La validez de ese instrumento normativo, conocido como Resolución 01/99, ha sido cuestionada por emprendedores morales dentro de la profesión, autoidentificados como cristianos evangélicos. Su actuación plantea un desafío más amplio a la posición de la Psicología como una profesión secular de base científica. La controversia creada por el desafío a las posiciones del CFP sobre homosexualidad y sobre religión extrapola el dominio de la Psicología y su reglamentación como ciencia y profesión para convertirse en una disputa sobre la política sexual en el Brasil. En este artículo exploramos el proceso por el cual la diversidad sexual se ha convertido en una cuestión contenciosa para la Psicología brasileña, que afecta la política y la reglamentación de la profesión.
\end{abstract}

Palabras clave: Psicología, Diversidad Sexual, Homosexualidad, Religión, Pentecostalismo.

\section{Introduction}

This paper addresses the current challenge that so-called "sexual reorientation therapies" represent to the scientific and professional development of Psychology in Brazil, as well as to the exercise and free expression of sexual orientation as a human right (Corrêa, \& Muntarbhorn, 2006). Adopting this interpretation in response to the demands of lesbian, gay, bisexual and trans (LGBT) activism (Câmara, 2002; Facchini, 2005), and adhering to international scientific and legal consensus on the matter, since 1999 the Federal Council of Psychology (CFP, by its Portuguese initials), institutional body that regulates the exercise of the discipline in the country, has implemented a ban against any public statement or practice by certified members of the profession leading to the promotion of understandings of homosexuality as a pathological entity, or treating it as such (Resolução CFP No 001/99, 1999). The validity of the normative instrument issued for that purpose, known as Resolution 01/1999 (Ibid.), has been contested mostly by professionals and public figures that promote a moral conservative agenda in national politics
(Macedo, 2017; Natividade, \& Oliveira, 2013). Such public actors usually associate their moral entrepreneurship and political activism to their religious convictions and identify themselves as Evangelical Christians, posing a broader challenge to the secular definition of Psychology as a science-based profession (Conselho Federal de Psicologia, 2015) ${ }^{1}$. The controversy created by these challenges to the CFP positions on homosexuality and on religion extrapolates the domain of Psychology and its regulation as a science and profession, and become one more dispute over sexual politics in Brazil (Carrara, 2015).

In this paper we explore the process by which sexual diversity becomes a contentious issue for Brazilian Psychology, and primary concern for the leadership of its official organ, affecting the politics and regulation of the profession. To lay the ground for our arguments, we first present an overview of three processes that meet at this controversy in Brazilian recent history: the evolution of the regulation of Psychology as profession; the rise of Evangelical Pentecostalism and the entry of its leadership into party politics; and the emergence of LGBT activism (originally known as

\footnotetext{
${ }^{1}$ The term used in Brazilian political debates, documents and literature on the regulation of religious affairs by the State is "laico/laicida$d e$," which refers to the norm of strict purification of State and of public affairs from any form of religious authority, therefore reserved to the private realm. In that context, the term 'secular' is descriptive of the actual separation of spiritual and worldly matters, in configurations which may admit a variety of arrangements for the regulation of religious affairs vis-à-vis the State (Montero, 2015).
} 
the Brazilian Homosexual Movement). Next, we trace a history of "reparative therapies" and of "ex-gay" ministries in Brazil and the United States, as well as that of self-identified "Christian psychologists" in the country. After establishing those contextual elements, we describe two initiatives aimed at the annulment of Resolution 01/99, one in Congress, and another in the Judiciary. To conclude, we point at the alignment of "gay cure" advocates with a broader anti-rights agenda in national politics.

\section{Methodology}

The primary sources of this research are public documents, open to examination at official websites and other digital social network platforms, including those issued by the state-level Council of Psychology and by the CFP; documents and reports issued by the Chamber of Deputies; and press reports. All empirical sources have been accessed online. We approach the documentary record of institutional processes with an ethnographic perspective; this means not only analyzing their textual content, but also understanding their performative effect, as well as their timing, location, and the assemblage of technological means involved in their production as social facts-including the various interpretations constructed about them. The background on the history of Psychology as profession in Brazil, on the transformations of the religious field, and on LGBT politics in Brazil comes exclusively from secondary sources.

\section{Psychology, Pentecostalism and sexual diversity: intersecting politics}

Two years after the first act regulating the profession of the psychologist in Brazil, in 1962 (Esch, \& Jacó-Vilela, 2012), a military coup in 1964 installed an authoritarian regime of military dictatorship that lasted twenty-one years. The institutionalization of the discipline occurred during this period of exception, marked by State censorship, prison and exile of political dissidents, and absence of a public sphere of debate (Coimbra, 2000). Firstly, it was during this period that college-level Psychology courses pro- liferated in Brazil (Russo, 2002). Secondly, the dictatorship period was also the stage for a significant transformation of the religious field-until then predominantly Catholic - with the emergence and quick growth of new evangelical denominations in metropolitan areas, that catered to a migrant industrial working class. The most expressive portion of those congregations especially belonged to Pentecostal denominations (Mariano, 2004), whose revivalist doctrine and liturgy is conceived as an inherently public performance (Giumbelli, 2013). Thirdly, in the late 1970's, despite the context of political and moral repression (Green, 1999), the first groups that eventually constituted the then-called Brazilian Homosexual Movement began to congregate, in the midst of "an exuberant national gay community" (Carrara, \& Simões, 2007) that had taken shape since at least the mid-20th Century.

\section{Brazilian Psychology}

In Brazil, as part of the institutionalization of the discipline, the first attempts to regulate the exercise of the profession and organize its professional body in the country date back to the early 1950s. The first Psychology course of the country was founded in Rio de Janeiro, linked to the Pontifical Catholic University (PUC-Rio) (Russo, 2002). Other courses inaugurated afterwards, also within Catholic higher-education institutions (Degani-Carneiro, 2013). A decade later, Federal Law \#4,119 of 1962 was passed in response to the demand of professionals who until then acted as educators for "psychotechnics" to be recognized as an autonomous profession. That is the first instrument that legislates over psychologists' training and qualification, and that sets guidelines for the exercise of the profession ${ }^{2}$. Also as a result of that legislation, the National Council of Education established the minimum curricula and training to obtain certification as psychologist in the Brazilian territory (Esch, \& Jacó-Vilela, 2012). After that, by Federal Law \#5,766 of 1971, the CFP and Regional Councils of Psychology (CRP, by their Portuguese initials) were created. That law grants them legal perso-

\footnotetext{
${ }^{2}$ Although the practice of psychoanalysis remained unregulated in Brazil, this legislation allowed professionals without a medical degree to offer psychotherapeutic treatment. Curiously, Christian associations are among those who demand the recognition of Psychoanalysis as a profession (Carvalho, 2007).
} 
nhood, and administrative and financial autonomy as public domain organizations.

The CFP sits in the Federal District of Brasilia and holds authority over all regional councils and jurisdictions across the national territory. As part of its attributions, the CFP dictates guidelines for the application of existing legislation defining the competences of practicing psychologists. It is also the duty of the CFP to elaborate and approve the Psychology Professional Code of Ethics, and to act as superior ethical review board for the profession. In turn, it is the attribution of CRP to oversee observance of the Professional Code of Ethics, and to impose sanctions for its violation. In that capacity, CRPs operate as regional ethical review boards (Macedo, 2017). It is mandatory for all certified psychologists in the country to follow the precepts in the CFP Professional Code of Ethics.

Between 1967 and 2005, four different versions of that code were issued by ordinance of the CFP - roughly one for each new decade. Its third version, issued in 1987 during a period of intense politization of Brazilian society in the wake of the democratic transition, banned psychologists from "inducing any political, philosophical, moral or religious conviction while in the exercise of their professional functions" (Resolução CFP No 002/87, 1987). Almost two decades later, the Code of 2005 further specified that ban, to include: "any political, philosophical, moral, ideological, religious conviction, of sexual orientation, or any type of prejudice" (Conselho Federal de Psicologia [CFP], 2005). That inclusion echoes the contents of the CFP Ordinance \# 01 of 1999, which "establishes norms for psychologists' activity in relation to the issue of sexual orientation" (Resolução CFP No 001/99, 1999) . $^{2}$ For two decades, CFP Ordinance \#01/99 not only has determined the scope of psychologists' role with regards to homosexuality but has also become grounds for a variety of public interventions in defense of equal rights for all sexual orientations, against prejudice and discrimination.

\section{Pentecostalism in Brazil}

A significant transition occurred in the Brazilian religious field over the past 50 years. Steadily increasing numbers of churchgoers have joined Protestant denominations. As in the rest of Latin America, the Catholic affiliation of the Brazilian population had remained unchallenged since the country's first national census, carried out in 1870. But starting in 1970, the number of self-identified Catholics has decreased in the same proportion that those who declare themselves as Evangelical has increased. The main motor in this process is to be found in the expansion of Pentecostal churches in Brazil.

Pentecostal Christian revivals and the proliferation of Pentecostal congregations are verified in developing countries around the world, most notoriously in the South Pacific, Africa, East and Southeast Asia, and particularly Latin America, where Brazil stands out with millions of believers. According to Mariano (2004), the rate of conversion to Pentecostalism and the steady growth of an already hefty contingent of adepts is an evidence of Pentecostal leaders' capacity to respond to the economic, social, cultural, political, and religious transformations that have taken place in Brazil over the past five decades. Despite the great numbers of "evangélicos" or "crentes" (as Pentecostal Evangelical "believers" are popularly known), and of the constant proliferation of new churches in the urban peripheries across the country, their congregations are highly concentrated in a small number of denominations. The Assembleia de Deus, the Congregação Cristã no Brasil, and the Igreja Universal do Reino de Deus (Universal Church of Christ, or IURD, as it is also known, by its initials in Portuguese) together gather $74 \%$ of Brazilian Pentecostals (Mariano, 2004).

The later belongs to the segment called neo-Pentecostal. Most of these churches are autochthonous, founded in the 1970s by Brazilian pastors. Their doctrine and liturgy are largely centered on spiritual warfare against the devil and its envoys on earth, and on Prosperity Theology. It is the fastest

\footnotetext{
${ }^{3}$ Resolution CFP 01/1999 states: "Art. 1 - Psychologists shall act in accordance to the ethical principles of the profession, notably those that prescribe non-discrimination and the promotion and well-being of people and humanity. Art. 2 - Psychologists should contribute with their knowledge to a reflection upon prejudice and to the elimination of all forms of discrimination and stigmatization against anyone with homoerotic behavior or practices. Art. 3 - Psychologists shall not take any action that favors the pathologization of homoerotic behavior or practices, nor shall they adopt any coercive action tending to guide homosexuals to unsolicited treatments. Sole Paragraph - Psychologists will not collaborate with events and services that propose the treatment or cure of homosexuality. Art. 4 - Psychologists will not speak or participate in public statements in the mass media that would reinforce existing social prejudice regarding homosexuals or refer to them as having any psychic disorder".
} 
growing segment among Brazilian Pentecostals. The "Universal," also known as IURD, and a producer and popularizer of televangelism, owns one of the main TV networks in the country. Neo-Pentecostal churches are arguably the best adapted to local values, both old and new. Their cults and community practices focus on promises of material prosperity by God's will, self-improvement, and emotional and physical healing (Mariano, 2004).

Evangelicals have been present in party politics since 1930, albeit in a small and discreet way, with the election of some historic Protestants to Congress (Freston, 1999). However, following the re-democratization of the country in 1985, a growing number of politicians have played this public identity as a political credential. The increase in the number of evangelical parliamentarians has been constant since 1986, and many of them have been involved in corruption scandals (Vital, \& Lopes, 2013). Although Evangelical leaders do not share a common political project, they belong to a number of mostly right-wing parties that compose the Evangelical Parliamentary Front or "bancada evangélica" ("Evangelical caucus"), which has actively aligned to interfere against LGBT rights, in issues such as marriage equality and the criminalization of homophobia (Vital, \& Lopes, 2013).

In Brazilian Protestantism, everyday theological practice and life choices reflect to a great degree pastoral dictates, also linked to the official discourse and tradition of each denomination (Gomes, 2006). Sexual morality is particularly addressed and preached upon by pastors and missionaries, and subject to scrutiny by the church community. Pentecostal leaders tend to rely on a literal reading of the Bible, and value the Old Testament (Machado, \& Piccolo, 2010). Therefore, among other "vices" (such as substance and alcohol abuse, domestic violence, and crime) fought as signs of weakness and the Devil's doing, the "liberation" from sexual deviance is a privileged subject of their preaching, counsel, and ritual prescriptions. Some constitute true manuals for the cure of "homosexualism," (as they call it) with instructions, specific techniques, and practical exercises (Natividade, 2008). Christian Pentecostals' belief in homosexuality as inherently evil extrapolates the historical condemnation of homosexuality by the Catholic Church (Green, 1999), and secularized homophobic values associated to patriarchal traditions, hygienist discourse, andmore recently_anti-LGBT rights backlash.

\section{LGBT politics}

Arguably, contemporary homophobic discourse by religious conservatives is shaped, to a great degree, as a reaction to LGBT visibility, legal recognition, and anti-discrimination public policies in the fields of health, education, and human rights. The then called "Brazilian Homosexual Movement" (MHB) organizations emerged in São Paulo and Rio de Janeiro in the late 1970s, in the context of the Brazilian society's response to the military rule, which involved a thriving counter-cultural, iconoclastic art scene, and intense political debate at the universities. If one contemplates the thriving gay scene in the 1960s and early 70s, in the form of cabarets, drag contests and social clubs, American historian and brazilianist James Green (1999) speculates that the ten year delay in the emergence of the MHB in comparison to Argentina, Mexico and Puerto Rico, was due to the wave of violent repression and censorship initiated by the military government with its Institutional Act \#5 (AI-5).

But by the end of the 1980s, there were about 20 homosexual organizations in the country (MacRae, 1990). In the 1980s, the homosexual movement saw in the clefts opened by the country's re-democratization the possibility of having its claims met, thus initiating a new style of activism and dialogue with state politics. It was at this intersection that the Grupo Gay da Bahia (Gay Group of Bahia), founded in 1980, led a successful national campaign to repeal paragraph 302.0 of the National Institute of Welfare and Social Security (INAMPS, by their Portuguese initials) Health Code that labeled homosexuality as a form of "sexual deviance and disorder" (Simões, \& Facchini, 2009).

A final milestone of the Brazilian democratic transition, the Constitutional Assembly of 1987, wrote the 1988 Federal Constitution. Gay activists saw this as an opportunity to include sexual orientation as grounds for discrimination in the Individual Rights and Guarantees section. This event highlights the growing importance of legal activism, and the framing of discrimination based on sexual orientation (and, more recently, gender expression) as human rights and civil rights issues. However, despite the support of many civil society organizations, the proposal met the strong opposition of Catholic and Evangelical delegates, who won the contest (Câmara, 2002). Sexual orientation remains until today not recognized as grounds for discrimination under federal law. 
Although the beginning of the AIDS epidemic meant a brief retreat, eventually, as in other developing countries, during the 1990s the MHB embraced the fight against AIDS (Facchini, 2005). Initially a protest movement that had "solidarity" as it main motto, mobilized by the rhetorical affirmation that "we all have AIDS ", the Brazilian AIDS Movement inaugurated alliances with government agencies, and a discreet, unprecedented influx of financial and organizational resources that helped the expansion of the MHB (Parker, 2002). Along the 1990s, the gay movement came to include community groups, political party chapters, NGOs, student associations, and religious groups as well (Carrara, \& Simões, 2007). Most importantly, this process also comported the diversification of the sexual identity categories encompassed by the movement (Facchini, 2005), to include lesbians, transvestites, transsexuals, and bisexuals.

Carrara and Simões (2007) argue that this militant experience, informed by the critical thinking of both scholars and activists, was as important as the partnership with government agencies and international organizations developed in the 2000s. This meant a boost in public visibility, particularly by means of yearly pride parades gathering millions in large and mid-size cities across the country, and increasing recognition of civil rights in courts, including marriage, by decision of the Federal Supreme Court (STF) in 2011. But this emphasis in court litigation also reflects the resistance of religious conservatives, who successfully blocked all legal reform initiatives by the LGBT movement in Congress.

\section{Homosexuality and confessional Psychology}

\section{"Reparative therapy" and the "ex-gay" ministries}

Exodus International, an interdenominational Christian organization, and the largest ex-gay ministry in the United States, founded in 1976, established branches in other countries (Waidzunas, 2015), including Latin America (Vaggione, \& Mujica, 2013). Despite Alan Chambers' apology to the gay community and the closure of Exodus International in the USA (Stefan, 2013), NARTH, the National Association for Research and Therapy of Homosexuality, continued to exist. The concept of "reparative therapy" was intro- duced by British scholar Elizabeth Moberly in the early 1980s. Known as Exodus' "secular arm”, NARTH promotes the use of psychotherapeutic techniques, and relies exclusively on claims that its members regard as "scientific," granting "reparative therapy" a different kind of legitimacy. In the 1990s its founder, clinical psychologist Joseph Nicolosi was well-known for his prolific activism in favor of the "prevention," "treatment", and "reorientation of homosexuality". He died in March 2017 at the age of 70 (Sadomir, 2017). Nicolosi's Aquinas Clinic, in Encino, CA, enjoyed prestige among enthusiasts of this approach (Waidzunas, 2015). Since then, many "psychotherapists associated with Christian fundamentalism in the United States" have adopted the term (Ford, 2001).

"Ex-gay," "reparative therapy," and "sexual reorientation," are different names for a heterogeneous, unconventional set of techniques of vague psychotherapeutic inspiration, often combined with Evangelical pastoral messages and liturgy, based on the belief that sexual orientation may be reversed (Ford, 2001; Waidzunas, 2015). In the perspective of "gay cure" promoters' biased and distorted psychoanalytic interpretation, homosexuality is read as a sign of immaturity and dysfunction that, with assistance, may be overcome and "reoriented" back to "normal" heterosexuality (Dean, \& Lane, 2001):

Although psychoanalysts have offered and claimed homosexual conversions since the time of Freud, "reparative therapy" has come to generically define talking cures that claim to change an individual's homosexual orientation to a heterosexual one. Although other treatment modalities such as aversion therapies and psychosurgery have also promised to "cure" homosexuality, the history of reparative therapies has become inexorably linked with that of psychoanalysis (Drescher, 1998, p. 6).

Aside from the dubious nature of such sort of claims themselves, the publicity and dissemination of this approach is also an attempt to (re)construct homosexuality as a controversial subject. That is, the clinical approach represented by reparative therapy, which conceives homosexuality as harmful to the individual and to society, emerged as a reaction to the depathologization of homosexuality (Dean, \& Lane, 2001; Waidzunas, 2015), associated to the public 
coming out of LGBT identities--arguably the result of decades of activism. By the end of the first decade of the 21st Century, all claims that sexual orientation could be reversed had been proven false by dominant science, considered symptoms of obscurantism, harmful, and violations of clinical and research ethics (Schroeder, \& Shidlo, 2001; Waidzunas, 2015).

A Report by the American Psychological Association Task Force on Appropriate Therapeutic Responses to Sexual Orientation released in 2009 (APA, 2009) established new parameters on the subject:

Self-report evidence for reorientation had been discredited, while testimonies of harm had been granted a bolstered status. Sexual orientation was understood in terms of physiological response that could not be therapeutically altered. Fixed sexual orientations existed in humans, although the ability or willingness to acknowledge them might vary, and therapists were now encouraged to defer to clients' self-definition of their identity in therapeutic processes (Waidzunas, 2015, p. 177).

Almost a decade later, in 2018, a report compiled by the Mattachine Society of Washington, on "The pernicious myth of conversion therapy: how Love in Action perpetrated a fraud on America" ( described the fraudulent practices of an Evangelical ministry under that name ${ }^{4}$. Both reports provide a compendium of the research on the concepts, techniques, and effects of "reparative therapy" on individuals. In addition to noting its low success rate, both reports warn about the harm caused to clients subjected to it, including low self-esteem, depression, social withdrawal, and sexual dysfunction.

However, despite the closure of Exodus International in the US in 2013, its offspring stayed active in several other countries, with significant autonomy and local grip. According to the organization's own records $s^{5}$, the creation of a Brazilian chapter of Exodus International dates back to the early 1980s, when local psychologist Esly Carvalho began to disseminate its word in the country. Between 1982 and 1986, she organized the first two "Christian Conferences on Homosexuality" in Brazil. Since 1988, when Carvalho released her book "Homosexuality: a Christian Approach", several "ex-gay" ministries have started independently across the country. In 1994 Carvalho was authorized by Exodus International to create Exodus Latin America, and in 2002 Exodus Brazil, its offspring, was created as a separate organization. With the support of Exodus International, Exodus Brazil became one of their largest local organizations in the world (Carvalho, 2007).

\section{Christian Psychology}

Exodus is neither the first nor the only Christian ministry to claim "psi" knowledge and credentials in Brazil ${ }^{6}$. Evangelicals have been invested in the institutionalization of Psychology since the 1960s. This has meant both the emergence of individuals and groups of self-identified Christian psychologists, and the creation of organizations that congregate them, as well as a growing number of evangelical pastors and lay members interested in becoming Psychology graduates (Carvalho, 2007; Degani-Carneiro, 2013; Macedo, 2017). Duarte, Heilbron, Barros, e Peixoto (2006) argue that the foreign missions that brought "Christian counseling" and "inner healing” to Brazil contributed to a progressive assimilation of psychological knowledge and practices as part of a broader Christian world vision promoted by evangelical ministries. Pastors and lay members would train in psychological techniques and create interdenominational ministerial missions capable of combining pastoral and clinical skills. This movement involved a "re-reading of psychology from a Biblical perspective and an emphasis on education and guidance to deal with emotional issues" (Duarte et al., 2006, p. 19).

The founding in 1976 of the Christian Psychologists and Psychiatrists Corps (CPPC), prestigious

\footnotetext{
${ }^{4}$ Conley, in his book "Boy Erased: A Memoir of Identity, Faith and Family", which inspired the film "Boy Erased: uma verdade anulada" (movie title in Brazil) which had its release canceled in Brazil, recounts his experience as a young homosexual in Love in Action (Conley, 2016).

${ }^{5}$ Recovered from http://exoduslatinoamerica.com/exodus/history-of-exodus/.

${ }^{6}$ In the local jargon, the apocope "psi" ("psych" in English) encompasses knowledge, practices, and professional credentials in the fields of psychiatry, psychology and psychoanalysis in a nonspecific manner (Russo, 2002, p. 7).
} 
among Evangelicals (Macedo, 2017), coincides with a period of intense presence and diffusion of psychoanalysis in Brazilian society, and of a variety of competing psychotherapeutic approaches that came along with the institutionalization of Psychology as a profession. In that context, however, rather than a theory or a specialty, Christian Psychology stands as a religious identity of a group of professionals.

As required by Resolution CFP 10/1997 (Resolução CFP No 10/97), elaborated to "discipline techniques in conflict with established scientific criteria in the field of Psychology," the certified practice as, and publicity of the title of psychologist must be in accordance with those scientific criteria. Furthermore, in the case of techniques or approaches that are not recognized by the CFP, article 2 of the Resolution states that they may be used as "additional resources," provided that: they are experimental, in accordance to the guidelines of the National Council of Health (the deliberative branch of the Ministry of Health); they respect the principles established by the Psychologist's Professional Code of Ethics; "the professional may show adequate qualification to develop that technique"; and that the client expressly declares knowledge of the experimental technique or practice utilized." Christian Psychology does not comply with those requirements, therefore, cannot be publicized as a title, therapeutic practice or approach. Brazilian authors who write on the subject are few, and their works (mostly books and brochures and, increasingly, online talks) circulate as popular and religious literature, outside academic and professional circles. Likewise, in contrast to the US, where "Christian" is often attached not only to psych certification, but is also claimed by nurses, social workers, etc., in Brazil fewif any-identify as Christian psychologists in association to their clinical practice.

Another is the case, however, in the religious sphere and, increasingly, in the national public sphere. It is now frequent that pastors add "psychologist" in their résumé, and that they evoke that title as a source of authority when they make public pronouncements. Such is the case of Silas Malafaia ${ }^{7}$, Pentecostal minister of an influential congregation in Rio de Janeiro. Malafaia is a notorious and prolific advocate against LGBT rights and was subject to disciplinary process by the Rio de Janeiro State Council of Psychology. Malafaia's case shows the role of psychological knowledge as a pastoral resource and a source of public authority, consistent with the process of 'psychologization' verified in Brazilian public culture over the past century ${ }^{8}$. It also shows the combined relevance of claims of professional authority, and of anti-LGBT rights discourse in the careers of conservative Evangelical politicians as moral entrepreneurs (Natividade, \& Oliveira, 2013).

\section{In defense of a secular profession}

Since the 1990s, especially after the rise of the Care for the Profession (Cuidar da Profissão, the name in Portuguese) movement and its victory for the CFP presidency, Psychology councils have been increasingly aligned with a Human Rights agenda along with social movements (Degani-Carneiro, 2013). Sexual orientation, framed as a human rights issue, has had a central role in debates about the ethics and politics of the health professions. Considering Psychology's integral involvement with subjectivity and identity, professionals are frequently challenged by sexuality issues (Kahhale, 2011). The visible presence of Evangelical Christians in the public sphere and their increasing involvement in national politics (Giumbelli, 2013; Vital, \& Lopes, 2013) have also shaped the debate about the role of religion in relation to psychologists' professional practice. On the one hand, it has incited claims of religious identity among professionals, and, on the other, it has challenged Psychology's secular foundations and commitments.

Imbued with the CFP's secular commitment to Human Rights, by the end of the 1990s, Resolution

\footnotetext{
${ }^{7}$ Evangelical pastor and psychologist Silas Malafaia, 55, leader of the Assembleia de Deus Vitória em Cristo Church, is one of the most respected Brazilian televangelists, having preached on network TV for some thirty years. He is vice-president of the Interdenominational Council of Evangelical Ministers of Brazil, an entity that congregates around 8,500 pastors of almost all the Evangelical denominations in the country. In his preaching he condemns abortion, drug use, and what he sees as an increase in the privileges of homosexuals.

${ }^{8}$ Brazilian anthropologist Luiz Fernando Dias Duarte highlights two levels of "psychologization" in modern Western culture: first, the general attribution of causality to an interior reality of the self; second, the systematic search for knowledge about this causality by scientific means. The process of secularization in modern Western culture generated the displacement of interiority out of the religious realm, and the constitution of Psychology as we know it today: a form of "scientific" knowledge about the mind and subjectivity. Subsequently, religious phenomena are now seen as an expression of the psyche, reversing the relationship of the previous tradition: from the "psychological" dimension of religiosity to a "psychological" thinking about religiosity (Duarte, 2005).
} 
CFP 01/1999 was issued in response to reports by LGBT activists about the existence of clinical practices, programs and in-patient facilities sponsored by Evangelical organizations that promoted what came to be nationally popularized as "gay cure." This official charter "establishes rules for psychological practice for psychologists in relation to issues of sexual orientation" (Resolução CFP No 001/99). The World Health Organization (WHO)'s removal of homosexuality from the International Classification of Diseases (ICD-10) (Drescher, 2015) serves as background to this regulatory instrument. Other professional organizations also followed on, issuing policy instruments that ban discrimination and harassment against homosexuals by members in the exercise of their professions. That is the case of Resolution \#489/2006 by the Federal Council of Social Service (Resolução CFESS $\mathrm{N}^{\circ}$ 489/2006). In the course of its existence, Resolution CFP 01/1999 has also been instrumental to the recognition of LGBT rights in other contexts as well. It is mentioned in family court rulings in favor of joint adoption by same-sex couples (Macedo, 2017; Macedo, \& Sívori, 2018).

The CFP also issued a series of papers advocating for a strictly secular definition of Psychology, promoting respect and value for the country's religious diversity. In a public note released in 2012, it recognized the role of religious faith and traditions in Brazilian culture, shaping the subjective dimensions of the self. The note invokes the value of religious freedom to present the Psychologist's Professional Code of Ethics to guarantee that "psychological services and techniques are based on psychological science, and not on [any particular] religious or otherwise conviction unrelated to profession" (Conselho Federal de Psicologia [CFP], 2005) ${ }^{9}$.

Subsequently, in 2013, the CFP issued a position paper on the competence of Psychology Councils to guarantee constitutional rights. The paper reiterates the secular status of Psychology as a scientific discipline, and that psychological theories are not equi- valent to, and should not be confused with religious dogma ${ }^{10}$. In addition to that, in 2015 the CFP launched a course on "Laicidade" (see footnote i), offered through its e-learning platform OrientaPsi ${ }^{11}$. According to the CFP (2015), the platform was meant to become a space for the debate and the expression of opinions by members of the category. The three topics included in the course's syllabus are expressive of its pluralist orientation: "the democratic foundations of laity;" "Laities: neutrality and multi-denomination;" and "Fundamental notes for a pluri-confessional secular democracy." In the following year, 2016, the São Paulo Regional Council of Psychology (CRP-SP) released a three-volume series on "Psychology, Secularism, and their Relation to Religion and Spirituality." The series was presented to create a space for dialogue and connection with religion, spirituality, and traditional knowledge, while taking a critical stand against fundamentalist perspectives.

In response to the argument that Resolution 01/99 would prevent psychologists from assist LGBTs who seek to reduce their psychic suffering caused by their sexual orientation, in 2013 the CFP issued a clarification note ${ }^{12}$, addressing interpretive misunderstandings about Resolution 01/99. It notes that that normative instrument does not prohibit the reception of those who are suffering with questions related to their sexuality, but only prevents psychologists from pathologizing homosexuality and from offering "treatments" to reverse it.

\section{Resolution 01/99 under attack}

In the twenty years since its inception, Resolution 01/99 has been challenged several times by congressional bills and court actions, with increasing public impact. Each action is accompanied by public campaigning and wins the attention of national media, becoming an opportunity for "gay cure" advocates to gain political protagonism. Their varied political and professional backgrounds, institutional affiliation,

\footnotetext{
9 "Public note by the CFP enlightening society and psychologists on psychology and religiosity in professional practice." Recovered fraom http://site.cfp.org.br/nota-pblica-do-cfp-de-esclarecimento-sociedade-e-so-psiclogaso-sobre-psicologia-e-religiosidade-no-exercio-profissional

${ }^{10}$ Recovered from http://site.cfp.org.br/wp-content/uploads/2014/02/Posicionamento-do-Sistema-Conselhos-de-Picologia-para-a-quest\% C3\% A3o-da-Psicologia -Religi\% C3\% A3o-e-Espiritualidade.pdf

11 "OrientaPsi launches its fifth online course: Laicidade," uploaded 10/9/2015. Recovered from http://site.cfp.org.br/

${ }^{12}$ CFP Clarification Note published on 05/07/2013. Recovered from http://site.cfp.org.br/
} 
and always intense public activity contribute to the formation of dense networks.

\section{Congressional challenges}

In 2013, a Legislative Decree Proposal (PDC 234/11) was submitted to the Federal House of Deputies by the opposition MP João Campos ${ }^{13}$, to halt the application of the sole paragraph of Art. 3, and of Art. 4 of Resolution 01/99 (Gama, 2017; Macedo, 2017; Macedo \& Sívori, 2018). That would mean legalizing clinical interventions by psychologists seeking to reverse patients' sexual orientation. A reprint of another project, registered as PDC 1640 by MP Paes de Lira ${ }^{14}$, with less impact (Gama, 2017), the 2012 version obtained national repercussion, and became popularly known as the "project for gay cure." Neither project, however, gained enough support to reach an assembly vote, and both were archived in their respective legislatures.

Three years later, in 2015, after significant changes in the composition of the House, now presided by Pastor Eduardo Cunha ${ }^{15}$, a public hearing was held in 2015 (Machado, 2017), to hear "ex-gays" at the Human and Minority Rights Commission (CDHM), at the initiative of Evangelical MP Marco Feliciano ${ }^{16}$, president of that commission at the time-publicly known, paradoxically, for his openly homophobic statements and his anti-rights activism. The hearing was attended both by supporters and detractors of reparative therapy, with some press and digital social media repercussion. Eight "ex-gays" were invited to give testimony about their experience. The speakers list in favor of the "ex-gay" cause included Marisa Lobo, one of its most prominent promoters in Brazil, who introduced herself as a "pro-family and pro-life activist" ${ }^{17}$. Other Evangelical legislators also spoke in favor of those causes ${ }^{18}$.
Toni Reis ${ }^{19}$, a well-known national LGBT leader, and other LGBT activists, as well as the vice president of the CFP spoke in defense of Resolution 01/99 and LGBT rights. All advocates of the "ex-gay" cause identified themselves as Evangelical. Other speakers, however, including Pastor Marco Feliciano and psychologist Marisa Lobo, avoided any biblical or religious references (Machado, 2017).

In her defense of "ex-homosexuals," Marisa Lobo describes them as victims of discrimination, as a "minority of a minority" ("minoria da minoria")— an argument also used by Pastor Feliciano. For her, subjects who opt for abandoning homosexuality are marginalized in society and in the family, and by the gay movement as well. Lobo also evokes a recurrent strategic reversal by anti-LGBT activists in Brazil, that of denouncing the "heterophobia," that "ex-gays" would presumably suffer, of the LGBT movement (Brasil, 2015).

The participation of the then vice president of the CFP, Rogério de Oliveira Silva, served as counterpoint to the emotional tone of this session; Silva responded to criticisms by "ex-gay" supporters that psychologists would "not welcome" clients "who say they want to leave the homosexual experience." To back his rebuttal, he referred to Resolution 01/99, whose guidelines do not prevent psychologists from caring for clients in psychic suffering, but rather contests the interpretation of that suffering as caused by an "ill" sexual orientation. His intervention was applauded by LGBT activists when he said that Psychology does not disregard their suffering. Rather, it cannot assume that homosexuality is amenable to treatment because it is not a pathology (Brasil, 2015). Arguably, the most evident accomplishment of "ex-gay" hearing was the demonstrative effect of the testimony of individuals who had supposedly "abandoned" homosexuality, granting material existence to this category.

\footnotetext{
${ }^{13}$ Evangelical deputy at the time linked to the PSDB.

${ }^{14}$ Former commander of the Military Police at the time linked to the PTC.

${ }^{15} \mathrm{~A}$ member of the MDB-affiliated evangelical group, he presided over the Chamber of Deputies at the time of the impeachment of President Dilma. Currently imprisoned in Curitiba accused of corruption and other crimes.

${ }^{16}$ Deputy pastor Marco Feliciano affiliated with the PSC noted for his vehemently homophobic statements.

${ }^{17}$ Note that, under the watch of Council of Psychology, Marisa Lobo did not call on her professional identity as psychologist.

${ }^{18}$ The next day another hearing was held, featuring a similar speakers list, in support of the Family Statute Bill, aimed against a recent ruling by the Federal Supreme Court legalizing same-sex unions (Machado, 2017).

${ }^{19}$ Toni Reis is the Executive Director of the Brazilian LGBTI organization called Grupo Dignidade. He is also the Secretary of Education of the Brazilian Association of Gays, Lesbians and Transgenders (ABGLT), of which he was president and founder in 1995. He is a member of the international board of the Hirschfeld-Eddy Foundation.
} 


\section{In court}

Legal action moved parallel to anti-rights activists' congressional activity. Now herself a lobbyist, congressional aide to the Pro-Life Caucus, Rozangela Justino was a psychologist best known in Brazil for her defense of reparative therapy. But she was the first psychologist to be punished for acting in disagreement with Resolution 01/99. In 2015, Justino issued a security mandate against Resolution $01 / 99$ at the Federal Public Ministry (MPF) of Rio de Janeiro. The Mandate originated a Public Civil Action filed by the $\mathrm{MPF}^{20}$, demanding the annulment of the Resolution. According to the claim by the MPF, this instrument "violates human rights by disallowing the psychological care of the LGBT population". In the same year the Action was dismissed by the 5th Federal Court of the Judiciary Section of Rio de Janeiro.

On September 2017, in the most recent episode of the objections to Resolution 01/1999, Rozangela Justino and twenty-two other psychologists collectively demanded at the 14th Federal District a motion to suspend the effects of Resolution 01/99 (Decisão Liminar, 2017). The civil action by the group headed by Justino portrays Resolution 01/99 as a true "act of censorship", that prevents psychologists from studying, consulting, and doing research on homoerotic behavior, "in detriment of the country's cultural and scientific heritage, insofar as it restricts psychologists' freedom of conducting scientific research" (Decisão Liminar, 2017). On September 15, 2017, at a hearing held in Brasilia, Federal Judge Dr. Waldemar Cláudio de Carvalho granted partial approval to that injunction. According to a public report of CFP, his ruling determined that the CFP should not prevent psychologists from promoting studies or relevant professional care seeking to "sexual (re)orientation". In December of that same year, the Judge changed his decision. In his new ruling, he states that "homosexuals in conflict" (with their sexual orientation) seeking care may be attended to, but psychologists may not "advertise" that sort of treatments. This represents a discreet achievement for "gay cure" advocates. In response to this court decision, several professional associations signed a public declaration in support of Resolution 01/99. One year later, in September 2018, the CFP filed a constitutional complaint ( $\mathrm{n}^{\circ}$ 31818) before the STF requesting the suspension of the effects of that ruling and the extinction of the action, in order to maintain the full effects of Resolution 01/99. On April 24, 2019, Minister Cármen Lúcia granted an injunction that determined that it was not for Psychology professionals in Brazil to offer any type of "sexual reversal" practice and determined the immediate suspension of the popular action, restating CFP Resolution 01/99, which "remains intact and effective". However, the injunction does not rule finally on the validity of Resolution CFP 01/99. The suspension determined by Justice Cármen Lúcia is valid while the core issue of "gay cure" is discussed by the plenary of the STF, at a yet unscheduled date.

In the meantime, while the validity of Resolution $01 / 99$ was being challenged in court, the CFP began to write another chapter in this story. In January 2018, the CFP issued Resolution 01/18, that "establishes norms of action for psychologists in relation to transsexuals and transvestites" (Resolução oo 1, 2018). In less than half a year, Resolution $01 / 18$ has already been challenged by two lawsuits filed by the MPF of Goiás. Both actions question its constitutionality and its legal basis. Both processes have been closed without merit.

\section{Council elections}

Elections for the CFP and CRP are held triennially. The 2016 election mobilized psychologists intensely in social media, particularly around human rights issues. The winning ticket for the 2017-19 triennium, "Care for the Profession: advancing Psychology with ethics and citizenship," was reelected to conduct the CFP for its second term. The ticket featured the defense of minority rights in its platform. Its opponent, the Psychology in Action movement, had a ticket made mostly of Evangelical psychologists, that came out third in the election, with about $10 \%$ of all valid votes. Critical of the current conduction of the CFP, the Psychology in Action movement calls for the "rescue of Psychology's scientificity," and for the end of party politics at "a Council that works and works around ideologies," in the words of one of its main representatives, psychologist Deuza Avellar, available on the group's social networks ${ }^{21}$.

\footnotetext{
${ }^{20}$ Ação Civil Pública 18794-17.2011.4.02.5101 - Memoriais CFP. Available at: http://site.cfp.org.br/ Accessed 12/12/2016.

${ }^{21}$ https://www.facebook.com/psicologosemacao/.
} 
Active in Facebook and Youtube, the Psychology in Action movement is systematic in its opposition to the current Council leadership. In the campaign for the 2019 election (to be held in the month of August), it advocates for the annulment of Resolutions 01/99 and $01 / 18$. Aligned with the anti-rights discourse of right-wing moral conservatives in educational politics, the ticket created the slogan "Psychology Without Party" ("Psicologia Sem Partido"), echoing the "School Without Party" movement, active in national politics (Miguel, 2016). The Psychology in Action movement also supports the "Pro-Life" cause (against legal abortion and other sexual and reproductive rights) and positions itself against "gender ideology" - a construct disseminated in Europe and American by Vatican thinkers in their anti-feminist and anti-LGBT rights campaigns (Junqueira, 2017)

\section{Conclusions}

Constitutional premises, rights and guarantees, such as freedom of religion, freedom of expression and scientific freedom, are also evoked in the defense of reparative therapy advocates. Resolution $01 / 99$ is portrayed as a gag rule that prevents well- -meaning, God-loving professionals from assisting clients who are in pain because of their ill sexual attraction towards persons of the same sex. The use by ultra-conservative groups of the tools of a normative framework that they otherwise question-that of liberal democracy, universal rights and guarantees-shows the complexity of the antagonisms they play on (Vaggione, 2013). Their skill to navigate different arenas and make use of different codesnamely, scientific, religious, and legal-shows that their discourse does not simply oppose scientific fact to religious faith or magic belief, nor does it raise religious actors against the secular state, but involves actors capable of strategically stand on one side or the other of these dichotomies. The challenges to Resolution 01/99 and activism in defense of the right to offer reparative therapy are but part of a broader conservative reaction to the conquests and protagonism in public arenas of feminist, LGBT, Black, and other movements seeking social justice (Burity, 2018). Montero (2015) has argued that dissent and criticism have become an increasingly recurrent mode of action by religious agents as they relate to each other and to the State.

\section{Referências}

American Psychological Association - APA. (2009). Report of the American Psychological Association task force on appropriate therapeutic responses to sexual orientation. Washingnton, DC: the author.

Brasil. Câmara dos Deputados. (2015). Comissão de Direitos Humanos e Minorias: Audiência de pessoas que deixaram de ser gays. Brasília, DF: o autor.

Burity, J. (2018). A onda conservadora na política brasileira traz o fundamentalismo ao poder? In R. Almeida, Conservadorismos, fascismos e fundamentalismos: análises conjunturais (pp. 15-66). Campinas, SP: Unicamp.

Câmara, C. (2002). Cidadania e orientação sexual: A trajetória do grupo Triângulo Rosa. Rio de Janeiro, RJ: Academia Avançada.

Carrara, S. (2015). Moralidades, racionalidades e políticas sexuais no Brasil contemporâneo. Mana, 21(2), 323-345. https://doi.org/10.1590/0104-93132015v21n2p323

Carrara, S., \& Simões, J. A. (2007). Sexualidade, cultura e política: a trajetória da identidade homossexual masculina na antropologia brasileira. Cadernos Pagu, (28), 65-99. https://ddoi.org/10.1590/S0104-83332007000100005

Carvalho, E. N. (2007). O divã e o altar: Cultura psicanalítica e movimento protestante no Brasil (Tese). Programa de Pós-Graduação em Antropologia Cultural, Universidade Federal do Rio de Janeiro, RJ, Brasil.

Coimbra, C. M. (2000). Doutrinas de Segurança Nacional: banalizando a violência. Psicologia em Estudo, 5(2), 1-22. https:// doi.org/10.1590/S1413-73722000000200002

Conley, G. (2016). Boy erased: A memoir of identity, faith and family. New York, NY: Riverhead.

Conselho Federal de Psicologia - CFP. (2005). Código de ética profissional do psicólogo Brasília, DF: o autor.

Conselho Federal de Psicologia - CFP. (2015). OrientaPsi. Recuperado de http://orientapsi.cfp.org.br/ 
Corrêa, S., \& Muntarbhorn, V. (2006). Princípios de Yogyakarta: Princípios sobre a aplicação da legislação internacional de direitos humanos em relação à orientação sexual e identidade de gênero. Rio de Janeiro, RJ: Centro Latino-Americano em Sexualidade e Direitos Humanos.

Dean, T., \& Lane, C. (2001). Homosexuality and psychoanalysis: an introduction. In T. Dean, \& C. Lane, Homosexuality and psychoanalysis (pp. 4-42). Chicago: The University of Chicago.

Decisão Liminar. (30, September 2017). Decisão Liminar. Brasília, DF, Brasil. Recovered from https://site.cfp.org. br/wp-content/uploads/2017/09/Decis\%C3\%A3o-Liminar-RES.-011.99-CFP.pdf

Degani-Carneiro, F. (2013). Psicólogos evangélicos: Interseção entre religiosidade e atuação profissional em Psicologia no Brasil (Dissertação). Curso de Psicologia, Centro de Educação e Humanidades, Universidade Estadual do Rio de Janeiro, Rio de Janeiro, RJ, Brasil.

Drescher, J. (1998). I'm your handyman: A history of reparative therapies. Journal of Homosexuality, 36(1), 19-42. https://doi.org/10.1300/J082v36n01_02

Drescher, J. (2015). Out of DSM: Depathologizing homosexuality. Behavioral Sciences, 5(4), 565-575. https://doi. org/10.3390/bs5040565

Duarte, L. F. (2005). Em busca do castelo interior: Roger Bastide e a psicologização no Brasil. In L. F. Duarte, J. Russo, \& A. T. Venancio, Psicologização no Brasil: Atores e autores (pp. 167-191). Rio de Janeiro, RJ: Contra Capa.

Duarte, L. F, Heilbron, M. L., Barros, M. L., \& Peixoto, C. (2006). Família, reprodução, e ethos religioso: subjetivismo e naturalismo como valores estruturantes. In L. F. Duarte, M. L. Heilbron, M. L. Barros, \& C. Peixoto, Família e religião (pp. 15-50). Rio de Janeiro, RJ: Contra Capa.

Esch, C. F., \& Jacó-Vilela, A. M. (2012). A regulamentação da profissão de psicólogo e os currículos de formação psi. In A. M. Jacó-Vilela, Clio-psiché hoje: Fazeres e dizeres psi na história do Brasil. Rio de Janeiro, RJ: Centro Edelstein de Pesquisas Sociais.

Facchini, R. (2005). Sopa de letrinhas? Movimento homossexuale produção de identidades coletivas nos anos 90. Rio de Janeiro, RJ: Garamond Universitária.

Ford, J. G. (2001). Healing homosexuals: a psychologist's journey through the ex-gay movement and pseudo science of reparative therapy. In A. Shidlo, M. Schoroeder, \& J. Drescher, Sexual research therapy: Ethical, clinical and research perspectives (pp. 69-86). New York, NY: The Haworth.

Freston, P. (1999). Protestantismo e democracia no Brasil. Lusotopis, 329-340.

Gama, M. C. (2017). Criminalização da homofobia e despatologização da homossexualidade no Congresso Nacional, da redemocratização à atualidade (Tese). Centro de Ciências Sociais, Instituto de Estudos Sociais e Políticos, Universidade do Estado do Rio de Janeiro, Rio de Janeiro, RJ, Brasil.

Giumbelli, E. (2013). Cultura publica: Evangelicos y su presencia en la sociedad brasileña. Sociedad y Religion, 23(40), 13-43.

Gomes, A. M. (2006). As representações sociais do corpo e da sexualidade no protestantismo brasileiro. Rever: Revista de Estudo da Religião, (1), 1-38.

Green, J. N. (1999). Beyond carnival: Male homosexuality in twentieth-century Brazil. Chicago, Ill: The University of Chicago Press.

Junqueira, R. D. (2017). Caso Anatrella e o silêncio dos "defensores da família”. Sexuality Policy Watch. Recuperado de http://sxpolitics.org/ptbr/caso-anatrella-e-o-silencio-dos-defensores-da-familia-o-que-acontece-quando-um-expoente-da-cruzada-antigenero-se-envolve-em-escandalos-sexuais/7800

Kahhale, E. M. (2011). Histórico do Sistema Conselhos de Psicologia e a interface com questões LGBTs. In C. R. Região, Psicologia e diversidade sexual: cadernos temáticos CRP/SP (pp. 20-24). São Paulo: CRP/SP.

Macedo, C. M. R. (2017). A "clínica pastoral" dos psicólogos cristãos no Brasil (Dissertação). Programa de Pós-graduação em Saúde Coletiva, Instituto de Medicina Social, Universidade do Estado do Rio de Janeiro, Rio de Janeiro, RJ, Brasil.

Macedo, C. M. R., \& Sívori, H. F. (2018). Repatologizando a homossexualidade: A perspectiva de "psicólogos cristãos" brasileiros no século XXI. Estudos \& Pesquisas em Psicologia, 18(4), 1415-1436. 
Machado, M. D. (2017). Pentecostais, sexualidade e família no Congresso Nacional. Horizontes Antropológicos, 23(47), 352-380. https://doi.org/10.1590/s0104-71832017000100012

Machado, M. D., \& Piccolo, F. D. (2010). Religiões e homossexualidades. Rio de Janeiro, RJ: FGV Editora.

MacRae, E. (1990). A construção da igualdade: identidade sexual e política no Brasil da "abertura". Campinas, SP: Editora Unicamp.

Mariano, R. (2004). Expansão pentecostal no Brasil: O caso da Igreja Universal. Estudos Avançados, 18(52): 121-138. https://doi.org/10.1590/S0103-40142004000300010

Mattachine Society of Washingtons (2018). The pernicious myth of conversion therapy: How love in action perpetrated a fraud on America. Washington, DC: the author.

Miguel, L. F. (2016). Da “doutrinação Marxista” à “ideologia de gênero”: Escola Sem Partido e as leis de mordaça no parlamento brasileiro. Direito \& Práxis, 590-621.

Natividade, M. (2008). Deus me aceita como eu sou?: A disputa sobre o significado da homossexualidade entre evangélicos no Brasil (Tese). Programa de Pós-Graduação em Antropologia Cultural, Universidade Federal do Rio de Janeiro, Rio de Janeiro, RJ, Brasil.

Natividade, M., \& Oliveira, L. D. (2013). As novas guerras sexuais: Diferença, poder religioso e identidades LGBT no Brasil. Rio de Janeiro,RJ: Garamond Universitária.

Parker, R. (2002). Abaixo do equador: Culturas do desejo, homossexualidade masculina e comunidade gay no Brasil. Rio de Janeiro, RJ: Record.

Resolução CFP No 001/99, de 22 de março de 1999. Estabelece normas de atuação para os psicólogos em relação à questão da Orientação Sexual". Recuperado de https://site.cfp.org.br/wp-content/uploads/1999/03/resolucao1999_1.pdf

Resolução CFP № 1, de 29 de janeiro de 2018. Estabelece normas de atuação para as psicólogas e os psicólogos em relação às pessoas transexuais e travestis. Recuperado de https://site.cfp.org.br/wp-content/uploads/2018/01/ Resolu\%C3\%A7\%C3\%A3o-CFP-01-2018.pdf

Resolução CFP No 002/87, de 15 de agosto de 1987. Aprova o Código de Ética Profissional do Psicólogo. Recuperado de https://transparencia.cfp.org.br/wp-content/uploads/sites/10/2005/05/Codigo-de-Etica-Profissional-do-Psicologo.pdf

Resolução CFP No 10/97, de 20 de outubro de 1997. Estabelece para divulgação, a publicidade e o exercício profissional do psicólogo, associados a práticas que não estejam de acordo com os critérios científicos estabelecidos no campo da Psicologia. Brasília, DF: the author.

Resolução CFESS N 489/2006, de 3 de junho de 2006. Estabelece normas vedando condutas discriminatórias ou preconceituosas, por orientação e expressão Sexual por pessoas do mesmo sexo, no exercício profissional do assistente social, regulamentando princípio inscrito no Código de Ética Profissional. Recuperado de http://www. cfess.org.br/pdf/resolucao_4892006.pdf

Russo, J. (2002). O mundo PSI no Brasil. Rio de Janeiro, RJ: Zahar.

Sandomir, R. (2017, March 16). Joseph Nicolosi, advocate of conversion therapy for gays, dies at 70. The New York Times. Recovered from https://www.nytimes.com/2017/03/16/us/ joseph-nicolosi-dead-gay-conversion-therapist.html

Schroeder, M., \& Shidlo, A. (2001). Ethical issues ins sexual orientation conversion therapies: an empirical study of consumers. In M. Schroeder, A. Shidlo, \& J. Drescher, Sexual research therapy: Ethical, clinical and research perspectives (pp. 131-166). New York, NY: The Haworth.

Simões, J. A., \& Facchini, R. (2009). Na trilha do arco-íris: Do movimento homossexual ao LGBT. São Paulo, SP: Fundação Perseu Abramo.

Vaggione, J. M. (2013). Laicidad y sexualidad. Ciudad de México, DF: UNAM.

Vaggione, J. M., \& Mujica, J. (2013). Algunos puntos de discusión en torno al activismo (religioso) conservador en América Latina. In J. M. Vaggione, \& J. Mujica, Conservadurismos, religión y política: perspectivas de investigación en América Latina (pp. 17-40). Córdoba: María Candelaria Sgró Ruata. 
Psicologia: Ciência e Profissão 2019 v. 39 (n.spe 3.), e228496,88-102.

Vital, C., \& Lopes, P. V. (2013). Religião e política: Uma análise da atuação de parlamentares evangélicos sobre direito das mulheres e de LGBTs no Brasil. Rio de Janeiro: Fundação Heinrich Böll \& Instituto de Estudos da Religião.

Waidzunas, T. (2015). The straight line: How the fringe science o ex-gay therapy reoriented sexuality. Minneapolis: University of Minnesota Press.

\section{Cleber Michel Ribeiro de Macedo}

Psicólogo. Mestre e doutorando em Saúde Coletiva pelo Instituto de Medicina Social da Universidade do Estado do Rio de Janeiro (IMS/UERJ).

E-mail: cleberribmacedo@gmail.com

(iD https://orcid.org/0000-0002-1817-7475

\section{Horacio Federico Sívori}

Professor Adjunto, Instituto de Medicina Social, Universidade do Estado do Rio de Janeiro (IMS/UERJ). Coordenador do Centro Latino-Americano em Sexualidade e Direitos Humanos (CLAM). www.clam.org.br

E-mail: hfsivori@gmail.com

(iD https://orcid.org/0000-0003-0103-1127

Apoio CAPES (Apoio à Pós-Graduação), CNPq (APQ Universal), FAPERJ (APQ).

Endereço para envio de correspondência:

Rua São Francisco Xavier $5246^{\circ}$ andar Bloco E

Maracanã. CEP 20550013 - Rio de Janeiro, RJ - Brasil

Recebido 10/09/2019

Aceito 04/10/2019

Received 09/10/2019

Approved 10/04/2019

Recibido 10/09/2019

Aceptado 04/10/2019

How to cite: Macedo, C. M. R. \& Sívori, H. F. (2019). EnvironmentalThe Sexual diversity debate in brazilian psychology: professional regulation at stake. Psicologia: Ciência e Profissão, 39 (n. spe 3), 88-102. https://doi.org/10.1590/1982-3703003228496

Como citar: Macedo, C. M. R. \& Sívori, H. F. (2019). O Debate sobre diversidade sexual na Psicologia Brasileira: regulamentação profissional em jogo. Psicologia: Ciência e Profissão, 39 (n.spe 3), 88-102. https://doi.org/10.1590/1982-3703003228496

Cómo citar: Macedo, C. M. R. \& Sívori, H. F. (2019). Psicología Ambiental y Recursos de Sostenibilidad: Revisión Integradora. Psicologia: Ciência e Profissão, 39 (n. spe 3), 88-102. https://doi.org/10.1590/1982-3703003228496 